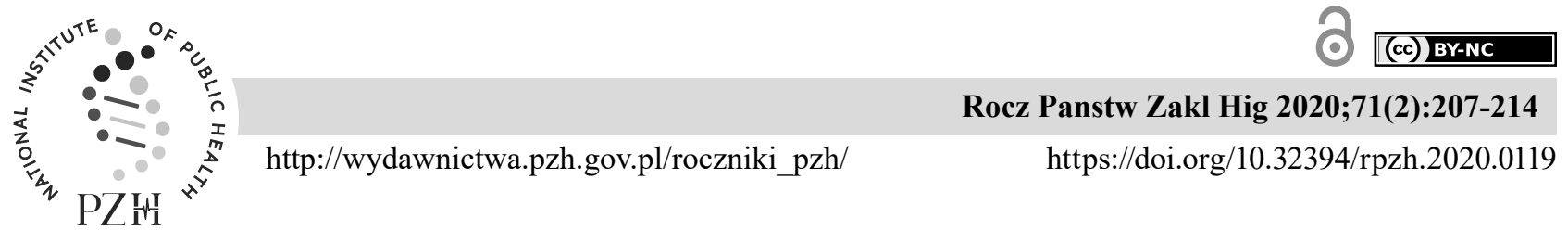

ORIGINAL ARTICLE

\title{
THE ASSOCIATION BETWEEN THE INSERTION/DELETION POLYMORPHISM OF THE ANGIOTENSIN CONVERTING ENZYME GENE AND HYPERTENSION, AS WELL AS ENVIRONMENTAL, BIOCHEMICAL AND ANTHROPOMETRIC FACTORS
}

\author{
Lucyna Pachocka ${ }^{1}$, Marta Włodarczyk², Longina Kłosiewicz-Latoszek ${ }^{1}$ Irena Stolarska ${ }^{1}$ \\ ${ }^{1}$ National Institute of Public Health - National Institute of Hygiene, Warsaw, Poland \\ ${ }^{2}$ Department of Biochemistry and Pharmacogenomics, Warsaw Medical University, Warsaw, Poland
}

\begin{abstract}
Background. Arterial hypertension is caused by environmental factors and genetic predisposition.

Objective. The aim of this study was to assess the association between the angiotensin converting enzyme (ACE) gene variants and environmental factors, biochemical and anthropometric parameters and the incidence of hypertension.

Material and methods. A total of 73 patients, aged 24 to 68, with Body Mass Index (BMI) above $25 \mathrm{~kg} / \mathrm{m} 2$ took part in this study. Nutrient intake was assessed with a diet based on consumption records. The ACE gene insertion/deletion (I/D) polymorphism was determined by the polymerase chain reaction (PCR) method.

Results. Normal pressure predominated in persons with genotype II (59.1\%), whereas hypertension in persons with genotype ID (55.2\%). The frequency of the D allele was 5\% higher in the hypertensive group (53\% vs. $48 \%$ ), but this difference was not statistically significant. The percentage of patients who consumed alcohol and smoked cigarettes in the $\mathrm{D}$ allele group was higher than in the I allele group. People with the D allele had lower vitamin D intake and higher copper intake than carriers of the allele I. The highest vitamin D intake was found in people with genotype II, and the differences were significant compared to patients with ID genotype. People with the D allele consumed more carbohydrates and less protein than those with the I allele, but these differences were not statistically significant.

Conclusions. Hypertensive subjects were more frequent DD and ID genotypes, whereas normotensive subjects - the II genotype. People with the D allele had lower vitamin D and protein intake, while the carbohydrate and copper intake was higher than those with the I allele. The group with the $\mathrm{D}$ allele had a higher percentage of smokers and alcohol drinkers. Our studies have shown a relationship between environmental and genetic factors and hypertension, but more research is needed.
\end{abstract}

Key words: hypertension, obesity, polymorphism ACE, lifestyle

\section{STRESZCZENIE}

Wprowadzenie. Nadciśnienie tętnicze jest spowodowane przez czynniki środowiskowe i predyspozycje genetyczne.

Cel. Celem badań była ocena związku pomiędzy wariantami genu ACE oraz czynnikami środowiskowymi, biochemicznymi i antropometrycznymi a występowaniem nadciśnienia.

Materiał i metody. W badaniu wzięło udział 73 pacjentów, w wieku od 24 do 68 lat, z BMI $>25 \mathrm{~kg} / \mathrm{m} 2$. Spożycie składników pokarmowych z dietą oceniano na podstawie zapisów spożycia. Polimorfizm I/D genu ACE określono metodą PCR. Wyniki. Prawidłowe ciśnienie dominowało u osób z genotypem II (59,1\%), natomiast nadciśnienie u osób z genotypem ID (55,2\%). Częstotliwość allelu D była większa o 5\% w grupie z nadciśnieniem (53\% vs. 48\%), jednak różnica ta nie była statystycznie istotna. Odsetek pacjentów, którzy spożywali alkohol i palili papierosy w grupie z allelem D był wyższy niż w grupie z allelem I. Osoby z allelem D charakteryzowały się niższym spożyciem witaminy D i wyższym spożyciem miedzi niż nosiciele allelu I. Największe spożycie witaminy D stwierdzono u osób z genotypem II, a różnice były znaczące w stosunku do pacjentów z genotypem ID. Ludzie z allelem D spożywali więcej węglowodanów i mniej białka niż osoby z allelem I, ale różnice te nie były istotne statystycznie.

Wnioski. U osób z nadciśnieniem tętniczym częściej występowały genotypy DD oraz ID, podczas gdy wśród osób z prawidłowym nadciśnieniem - genotyp II. U osób z allelem D było niższe spożycie witaminy D i białka, natomiast większe było spożycie węglowodanów i miedzi niż u osób z allelem I. W grupie z allelem D stwierdzono większy odsetek osób palących papierosy i pijących alkohol. Nasze badania wykazały związek pomiędzy czynnikami środowiskowymi i genetycznymi oraz nadciśnieniem, ale niezbędne są dalsze analizy w tym obszarze.

Słowa kluczowe: nadciśnienie tętnicze, otyłość, polimorfizm ACE, styl życia

Corresponding author: Lucyna Pachocka, Medical Center, National Institute of Public Health - National Institute of Hygiene, Powsińska 61/63, 02-903 Warsaw, Poland, phone: +48 691539427; e-mail: lpachocka@pzh.gov.pl

(c) Copyright by the National Institute of Public Health - National Institute of Hygiene 


\section{INTRODUCTION}

Hypertension is caused by environmental factors and/or genetic predisposition. These environmental factors include inappropriate nutrition, little physical activity, and smoking. Hypertension very frequently co-exists with obesity, dyslipidemia, or diabetes mellitus. These interrelations have been the topic of many studies [17, 30]. Recent years have seen the publication of study results on the relationship between candidate genes and blood pressure [28]. One of the recent areas of interest involves the associations of polymorphic genes that code certain components of the rennin-angiotensine-aldosterone (RAA) system [2]. The RAA system is one of the most important body regulators affecting arterial blood pressure, the sympathetic system, water and salts intake, and vascular inflammation [16].

Angiotensin-converting enzyme (ACE) activity plays an important regulatory role in the RAA system. The gene coding the ACE has been shown to be located on long arm of chromosome 17 [19]. ACE gene polymorphism (rs1799752) is a result of the presence (insertion, I) or absence (deletion, D) of a segment, 287 base pairs long. This polymorphism manifests by the existence of three genotypes: two homozygous genotypes, II and DD, and one heterozygous genotype, ID. People with genotype DD have demonstrated almost two times higher activity of the ACE than the II homozygotes [2, 19]. The ACE gene I/D polymorphism is most commonly described in the context of predisposition for developing hypertension and cardiovascular disease, however, only a few papers have been written on the interaction of I/D polymorphism with environmental factors, e.g. with sodium content in the diet, which may considerably modify its expression [2].

The aim of this study was to assess the relationship between the ACE gene I/D polymorphism and the frequency of hypertension, selected environmental factors as well as biochemical and anthropometric factors in a group of subjects with BMI $>25 \mathrm{~kg} / \mathrm{m}^{2}$.

\section{MATERIAL AND METHODS}

The study was conducted in 73 patients ( 42 females and 31 males) aged 24 to 68 with the BMI of $>25 \mathrm{~kg}$ / $\mathrm{m}^{2}$. The research project was approved by the Bioethics Committee at the Institute of Food and Nutrition in Warsaw. Subjects with a history of myocardial infarction; stroke; heart failure; disease of the kidneys, liver, thyroid; or type 1 diabetes were excluded from the study. A survey based on a the authors questionnaire yielded data on the subjects, life styles: alcohol consumption, smoking, type of physical activity, as well as information on the treatment of hypertension.
Physical activity was defined as $0.5-1$ hour of walking, cycling, or swimming 2-3 times a week. All subjects underwent blood pressure measurements conducted with OMRON M6, according to standards of care in hypertension. Hypertension was defined as either systolic blood pressure of 140 and/or diastolic pressure of $90 \mathrm{mmHg}$ or the use of hypotensive drugs (mean of 3 separate measurements).

Anthropometric measurements (height and weight, as well as waist and hip circumferences) were conducted according to the WHO guidelines. The type of obesity was assessed based on the WHR index (waist to hip ratio) - waist circumference / hip circumference. The diagnostic criterion for abdominal obesity was WHR of 0.8 in women and WHR of 1.0 in men $[5,26]$.

The subjects' diet was assessed based on continuous 3-day food intake records, and the results were compared against the recommended levels and safety norms. The mean Physical Activity Level (PAL) of 1.6 was assumed for subjects declaring a lack of physical activity and 1.75 for those who were physically active [8]. Energy consumption and the intake of selected nutrients was calculated with "Diet 4" using a database developed at the National Food and Nutrition Institute in Warsaw[11].

Blood chemistry: serum glucose, sodium, total cholesterol (TC), triglycerides (TG), and HDLcholesterol (HDL-C) tests were conducted with the use of a VITROS-250 biochemical analyzer, Johnson \& Johnson Ortho Clinical Diagnostics, and LDLcholesterol (LDL-C) levels were calculated with the Friedewald's formula.

DNA was isolated from $1 \mathrm{ml}$ samples of venous blood with the DNA Blood Mini Kit (A\&A Biotechnology, Poland). Polymorphism I/D of the ACE gene was assessed by polymerase chain reaction (PCR) using primers sequences previously described [13]. The reactions were conducted in a PTC-200 MJ Research cycler in the following conditions: initial amplification 7 minutes at $94^{\circ} \mathrm{C}$, followed by 35 cycles of: denaturation 30 seconds at $94^{\circ} \mathrm{C}$, annealing of primers 45 seconds at $67^{\circ} \mathrm{C}$, and extension 1 minute at $72^{\circ} \mathrm{C}$, and final extension 7 minutes at $72^{\circ} \mathrm{C}$. The PCR yielded the following DNA fragments: 319 base pairs long fragments for the D allele, 597 base pairs long fragments for the I allele. Due to the phenomenon of preferential amplification of shorter DNA fragments (allele D) and the resulting risk of underestimating the actual frequency of the ID genotype, another PCR assay was run in samples from homozygotic DD subjects using a pair of starters specific for the I allele. The presence of a 335 base pairs long PCR product confirmed the ID genotype, whereas the lack of this product confirmed the DD homozygote. The PCR-generated fragments were 
separated via electrophoresis in a $2 \%$ agarose gel with ethidium bromide staining and photographed under UV light.

The frequencies of the individual genotypes were compared with the chi-square test. The results were compared with the t-Student test for paired and unpaired samples. Also, nonparametric statistics were calculated with the Kolmogorov-Smirnov test with the use of STATISTICA 6 software.

\section{RESULTS}

\section{Connection between genes and the presence of hypertension and lipid disorders}

The mean BMI value in the study group $(\mathrm{n}=$ 73) was $35.8 \pm 5.7 \mathrm{~kg} / \mathrm{m}^{2}\left(34.8 \mathrm{~kg} / \mathrm{m}^{2}\right.$ in women and $37.3 \mathrm{~kg} / \mathrm{m}^{2}$ in men). Abdominal obesity was observed in $63 \%$ patients: $(90.5 \%$ among women and $48,4 \%$ among men). The mean blood pressure value in the study group was $137 / 87 \mathrm{mmHg}$. Hypertension was detected in 36 subjects $(49.3 \%)$.

There was a similar frequency of II and ID genotypes in the normotensive group. The hypertensive group demonstrated nearly $20 \%$ greater frequency of ID genotypes vs. II genotypes. Fifty-nine percent of subjects with the II variant of the ACE gene were normotensive, whereas the majority $(55.2 \%)$ of subjects with the ID genotype were hypertensive (Table 1). The frequency of the $\mathrm{D}$ allele was greater by $5 \%$ in the hypertensive group (53\% vs. $48 \%$ ), however, this difference was not statistically significant $\left(\chi^{2}=1.02\right.$; $\mathrm{P}=0.5993$ ).

Table 1 demonstrates that allele D carriers have higher systolic and diastolic blood pressure values in comparison to those found in II homozygotes. The differences between systolic and diastolic blood pressure values between groups representing genotypes ID and II were statistically significant $(p<0.05)$. The greatest number of subjects with abdominal obesity (according to ATP III criteria) was found in the group of genotype II. The proportion of subjects who consumed alcohol and smoked cigarettes in the group of genotype DD was higher than that in groups characterized by the ID and II genotypes.

Total cholesterol and LDL-cholesterol levels differed significantly between the genotypes (Table 2). The highest levels of total cholesterol and LDLcholesterol were found in genotype ID subjects, with

Table 1. Clinical parameters and environmental factors in the study population stratified by ACE genotypes

\begin{tabular}{|c|c|c|c|}
\hline & \multicolumn{3}{|c|}{ Genotype } \\
\hline & $\begin{array}{c}\text { DD } \\
n=22\end{array}$ & $\begin{array}{c}\text { ID } \\
n=29\end{array}$ & $\begin{array}{c}\text { II } \\
n=22\end{array}$ \\
\hline $\begin{array}{l}\text { Total } n=73(100 \%) \\
\text { Women, } n=42(57.5 \%) \\
\text { in Women }(100 \%) \\
\text { Men, } n=31(43.5 \%) \\
\text { in Men }(100 \%)\end{array}$ & $\begin{array}{c}30 \% \\
10 \\
(23.8 \%) \\
12 \\
(38.7 \%)\end{array}$ & $\begin{array}{c}40 \% \\
17 \\
(40.5 \%) \\
12 \\
(38.7 \%)\end{array}$ & $\begin{array}{c}30 \% \\
15 \\
(35.7 \%) \\
7 \\
(22.6 \%)\end{array}$ \\
\hline $\begin{array}{l}\text { Hypertensive, } n=36(49.3 \%) \\
\text { Normotensive, } n=37(50.7 \%)\end{array}$ & $\begin{array}{c}11(31 \%) \\
{[50 \% \text { in DD] }} \\
11(30 \%) \\
{[50 \% \text { in DD] }}\end{array}$ & $\begin{array}{c}16(44 \%) \\
{[55.2 \% \text { in ID] }} \\
13(35 \%) \\
{[44.8 \% \text { in ID] }}\end{array}$ & $\begin{array}{c}9(25 \%) \\
{[40.9 \% \text { in II] }} \\
13(35 \%) \\
{[59.1 \% \text { in } \mathrm{II}]}\end{array}$ \\
\hline & $\mathrm{x} \pm \mathrm{SD}$ & $\mathrm{x} \pm \mathrm{SD}$ & $\mathrm{x} \pm \mathrm{SD}$ \\
\hline Age (years) & $49.7 \pm 11.7$ & $50.6 \pm 11$ & $51.5 \pm 12$ \\
\hline $\mathrm{SBP}(\mathrm{mm} \mathrm{Hg})^{\mathrm{a}}$ & $135.1 \pm 19.3$ & $141.7 \pm 11.7$ & $132.1 \pm 15.2$ \\
\hline $\mathrm{DBP}(\mathrm{mm} \mathrm{Hg})^{\mathrm{b}}$ & $86.4 \pm 16.7$ & $89.7 \pm 7.9$ & $85.1 \pm 7.4$ \\
\hline Body mass (kg) & $102 \pm 28$ & $104.8 \pm 15.7$ & $99.8 \pm 18$ \\
\hline $\operatorname{BMI}\left(\mathrm{kg} / \mathrm{m}^{2}\right)$ & $34.6 \pm 6.3$ & $37 \pm 5.6$ & $35.6 \pm 5.2$ \\
\hline $\mathrm{BMI}>30\left(\mathrm{~kg} / \mathrm{m}^{2}\right), \mathrm{n}(\%)$ & $13(59 \%)$ & $19(66 \%)$ & $18(82 \%)$ \\
\hline Waist circumference, $\mathrm{n}(\%)$ & $14(63.6 \%)$ & $18(62 \%)$ & $12(54.5 \%)$ \\
\hline WHR, n (\%) & $11(50 \%)$ & $12(41.4 \%)$ & $10(45.5 \%)$ \\
\hline Alcohol consumption, $\mathrm{n}(\%)$ & $14(63.6 \%)$ & $18(62 \%)$ & $12(54.5 \%)$ \\
\hline Physical activity, n (\%) & $11(50 \%)$ & $12(41.4 \%)$ & $10(45.5 \%)$ \\
\hline Smokers, n (\%) & $7(31.8 \%)$ & $6(20.7 \%)$ & $4(18.2 \%)$ \\
\hline
\end{tabular}

BMI - body mass index; SBP - systolic blood pressure; DBP - diastolic blood pressure; Waist circumference $\geq 88 \mathrm{~cm}$ in women and $\geq 102 \mathrm{~cm}$ in men; WHR - waist to hip ratio $\geq 0.8$ in women and $\geq 1.0$ in men; Physical activity was defined as 0.5-1 hour of walking, cycling or swimming 2-3 times a week;

aID a II $(\mathrm{p}<0.05)$; ${ }^{\mathrm{b}}$ ID a II $(\mathrm{p}<0.05)$. 
the differences in the values of these parameters in comparison to those in the genotype II group being statistically significant. The highest triglyceride and glucose levels were found in the DD homozygote group, who derived the highest percentage of energy from carbohydrates (Table 3).

\section{Connection between genes and intake of selected nutrients}

The evaluated genotype groups differ significantly in copper, vitamin $\mathrm{D}$, and dietary fiber consumption (Table 3). Copper consumption in all the evaluated genotype groups exceeded the recommended norms for Polish population [8]. Conversely, vitamin D consumption was insufficient. Consumption of dietary fiber was also unsatisfactory, with the lowest intake observed in the genotype II group. Subjects with the DD genotype tended to consume more carbohydrates than subjects with either the ID or the II genotype.

There were no significant differences in the consumption of energy and the evaluated nutrients in either the hypertensive or the normotensive subjects with the individual genotypes (Table 4).

The II genotype group showed statistically significantly higher triglyceride levels in hypertensive subjects in comparison to those found in normotensive subjects $(157.9 \pm 61.4 \mathrm{mg} / \mathrm{dL}$ vs. $96.5 \pm 43.9 \mathrm{mg} / \mathrm{dL})$. The hypertensive and normotensive groups did not differ significantly with respect to the remaining blood chemistry and anthropometric parameters (Table 5). Statistically significant differences between the hypertensive and normotensive subjects with the DD genotype were, however, demonstrated in the values of systolic blood pressure, of $148 \mathrm{mmHg}$ and 123 $\mathrm{mmHg}$ and and diastolic blood pressure, of $99 \mathrm{mmHg}$ and $75 \mathrm{mmHg}$, respectively. Subjects with DD and ID genotypes from the hypertensive group were noted to have higher systolic and diastolic blood pressure values than normotensive subjects.

Table 2. Blood chemistry parameters stratified by ACE gene variants

\begin{tabular}{|l|c|c|c|}
\hline \multicolumn{1}{|c|}{ Biochemical parameters } & DD & ID & II \\
\hline TG $(\mathrm{mmol} / \mathrm{l})$ & $\mathrm{x} \pm \mathrm{SD}$ & $\mathrm{x} \pm \mathrm{SD}$ & $1.6 \pm 0.8$ \\
\hline TC $(\mathrm{mmol} / \mathrm{l})^{\mathrm{a}}$ & $1.7 \pm 1.1$ & $5.5 \pm 1.1$ & $4.7 \pm 0.9$ \\
\hline HDL-C $(\mathrm{mmol} / \mathrm{l})$ & $5.0 \pm 1.0$ & $1.3 \pm 0.4$ & $1.4 \pm 0.3$ \\
\hline LDL-C $(\mathrm{mmol} / \mathrm{l})^{\mathrm{b}, \mathrm{c}}$ & $1.4 \pm 0.5$ & $3.4 \pm 1.0$ & $2.7 \pm 0.8$ \\
\hline Glucose $(\mathrm{mmol} / \mathrm{l})$ & $2.8 \pm 0.6$ & $5.7 \pm 0.9$ & $5.6 \pm 0.3$ \\
\hline Sodium $(\mathrm{mmol} / \mathrm{l})$ & $5.9 \pm 2.2$ & $142.8 \pm 2.1$ & $142.1 \pm 1.7$ \\
\hline
\end{tabular}

TG- triglycerides; TC- total cholesterol; HDL - High Density Lipoprotein; LDL - Low Density Lipoprotein;

${ }^{\mathrm{a}}$ ID vs II $(\mathrm{p}=0.01) ;{ }^{\mathrm{b}} \mathrm{DD}$ vs ID $(\mathrm{p}=0.028) ;{ }^{\mathrm{c}} \mathrm{ID}$ vs II $(\mathrm{p}=0.01)$

Table 3. Consumption of energy and nutrients stratified by ACE gene variants

\begin{tabular}{|c|c|c|c|}
\hline Energy and nutrients & DD & ID & II \\
\hline & $\mathrm{x} \pm \mathrm{SD}$ & $\mathrm{x} \pm \mathrm{SD}$ & $\mathrm{x} \pm \mathrm{SD}$ \\
\hline Energy (MJ) & $7.4 \pm 2.7$ & $8,0 \pm 2.8$ & $7.7 \pm 2.2$ \\
\hline Total protein $(\mathrm{g})$ & $79 \pm 26.2$ & $85.6 \pm 28.2$ & $94.7 \pm 34.9$ \\
\hline$\%$ energy from protein & 17.8 & 17.8 & 21.1 \\
\hline Fat $(\mathrm{g})$ & $68.6 \pm 35.2$ & $82.3 \pm 46.0$ & $77.0 \pm 30.8$ \\
\hline$\%$ energy from fat & 34.8 & 38.6 & 38.7 \\
\hline Carbohydrates $(\mathrm{g})$ & $210.7 \pm 92.6$ & $209.4 \pm 72.1$ & $189.9 \pm 82.1$ \\
\hline$\%$ energy from carbohydrates & 47.4 & 43.6 & 42.4 \\
\hline Sodium (mg) & $1907.1 \pm 886.0$ & $2024.9 \pm 142.7$ & $2001 \pm 1023.7$ \\
\hline Potassium (mg) & $2908.3 \pm 1175.3$ & $3414.8 \pm 1058.2$ & $3155.1 \pm 1070.8$ \\
\hline Calcium (mg) & $562.9 \pm 231.4$ & $645.8 \pm 273.1$ & $709.9 \pm 300.7$ \\
\hline Copper $(\mathrm{mg})^{\mathrm{a}}$ & $1.14 \pm 0.44$ & $1.35 \pm 0.52$ & $1.10 \pm 0.28$ \\
\hline Vitamin D (ug) $^{\mathrm{b}}$ & $4.01 \pm 3.12$ & $2.90 \pm 1.74$ & $5.38 \pm 5.15$ \\
\hline Dietary fiber $(g)^{c}$ & $20.2 \pm 10.8$ & $24.2 \pm 9.8$ & $19.1 \pm 7$ \\
\hline
\end{tabular}

${ }^{\mathrm{a} I D}$ vs II $(\mathrm{p}<0.05)$; ${ }^{\mathrm{b}}$ ID vs II $(\mathrm{p}<0.02)$; ${ }^{\mathrm{I}} \mathrm{ID}$ vs II $(\mathrm{p}<0.05)$ 
Table 4. The consumption of energy and the evaluated nutrients in hypertensive and normotensive subjects, stratified by ACE genotypes

\begin{tabular}{|c|c|c|c|c|c|c|}
\hline & \multicolumn{3}{|c|}{ Hypertensive } & \multicolumn{3}{|c|}{ Normotensive } \\
\hline & $\begin{array}{c}\mathrm{DD} \\
\mathrm{n}=11\end{array}$ & $\begin{array}{c}\text { ID } \\
n=16\end{array}$ & $\begin{array}{c}\mathrm{II} \\
\mathrm{n}=9\end{array}$ & $\begin{array}{c}\mathrm{DD} \\
\mathrm{n}=11\end{array}$ & $\begin{array}{c}\text { ID } \\
n=13\end{array}$ & $\begin{array}{c}\text { II } \\
n=13\end{array}$ \\
\hline \multicolumn{7}{|c|}{ Energy and nutrients } \\
\hline & $\mathrm{x} \pm \mathrm{SD}$ & $\mathrm{x} \pm \mathrm{SD}$ & $\mathrm{x} \pm \mathrm{SD}$ & $\mathrm{x} \pm \mathrm{SD}$ & $\mathrm{x} \pm \mathrm{SD}$ & $\mathrm{x} \pm \mathrm{SD}$ \\
\hline Energy (MJ) & $7.8 \pm 3.1$ & $7.99 \pm 3.4$ & $7.4 \pm 1.5$ & $6.7 \pm 2.4$ & $7.3 \pm 1.8$ & $7.4 \pm 2.6$ \\
\hline Total protein $(\mathrm{g})$ & $82.9 \pm 24.9$ & $89.5 \pm 35.0$ & $101.9 \pm 44.8$ & $75.1 \pm 28.1$ & $80.8 \pm 16.6$ & $90.3 \pm 28.0$ \\
\hline Fat $(\mathrm{g})$ & $73.7 \pm 39.0$ & $88.9 \pm 55.9$ & $75.3 \pm 31$ & $63.6 \pm 32.1$ & $74.1 \pm 30$ & $75.7 \pm 31.9$ \\
\hline Carbohydrates (g) & $224.6 \pm 91.6$ & $209.7 \pm 83.6$ & $184.7 \pm 77.9$ & $196.9 \pm 95.9$ & $209.0 \pm 58.2$ & $183.7 \pm 83.9$ \\
\hline Sodium (mg) & $\begin{array}{c}2146.0 \pm \\
903.1\end{array}$ & $\begin{array}{c}2227.6 \pm \\
1237.9\end{array}$ & $\begin{array}{c}1744.9 \pm \\
1009.5\end{array}$ & $\begin{array}{c}1668.2 \pm \\
841.0\end{array}$ & $\begin{array}{c}1775.3 \pm \\
706.7\end{array}$ & $\begin{array}{c}2206.4 \\
\pm 1075.9\end{array}$ \\
\hline Potassium (mg) & $\begin{array}{c}2916.7 \pm \\
1151.9\end{array}$ & $\begin{array}{c}3695.3 \pm \\
1159.4\end{array}$ & $\begin{array}{c}2947.3 \pm \\
1320.7\end{array}$ & $\begin{array}{c}2899.8 \pm \\
1254.6\end{array}$ & $\begin{array}{c}3069.4 \pm \\
835.7\end{array}$ & $\begin{array}{c}3360.1 \pm \\
898.6\end{array}$ \\
\hline Calcium (mg) & $555.7 \pm 226.6$ & $687.6 \pm 283.0$ & $811.4 \pm 377.2$ & $570.0 \pm 247.0$ & $594.3 \pm 262.1$ & $666.2 \pm 211.8$ \\
\hline Copper (mg) & $1.1 \pm 0.4$ & $1.5 \pm 0.6$ & $1.1 \pm 0.3$ & $1.2 \pm 0.5$ & $1.2 \pm 0.4$ & $1.1 \pm 0.3$ \\
\hline Vitamin D (ug) & $4.3 \pm 2.6$ & $3.1 \pm 2.1$ & $5.8 \pm 6.6$ & $3.8 \pm 3.6$ & $2.7 \pm 1.0$ & $4.9 \pm 4.3$ \\
\hline Dietary fiber $(\mathrm{g})$ & $21.8 \pm 12.1$ & $25.6 \pm 12.0$ & $17.5 \pm 6.4$ & $18.7 \pm 9.6$ & $22.3 \pm 6.1$ & $19.3 \pm 7.1$ \\
\hline
\end{tabular}

Table 5. Blood chemistry parameter levels and anthropometric factors in hypertensive and normotensive subjects, stratified by ACE genotype

\begin{tabular}{|l|c|c|c|c|c|c|}
\hline \multirow{2}{*}{} & \multicolumn{3}{|c|}{ Hypertensive } & \multicolumn{3}{c|}{ Normotensive } \\
\cline { 2 - 7 } & $\begin{array}{c}\mathrm{DD} \\
\mathrm{n}=11\end{array}$ & $\begin{array}{c}\mathrm{ID} \\
\mathrm{n}=16\end{array}$ & $\begin{array}{c}\mathrm{II} \\
\mathrm{n}=9\end{array}$ & $\begin{array}{c}\mathrm{DD} \\
\mathrm{n}=11\end{array}$ & $\begin{array}{c}\text { ID } \\
\mathrm{n}=13\end{array}$ & $\begin{array}{c}\text { II } \\
\mathrm{n}=13\end{array}$ \\
\hline & $\mathrm{x} \pm \mathrm{SD}$ & $\mathrm{x} \pm \mathrm{SD}$ & $\mathrm{x} \pm \mathrm{SD}$ & $\mathrm{x} \pm \mathrm{SD}$ & $\mathrm{x} \pm \mathrm{SD}$ & $\mathrm{x} \pm \mathrm{SD}$ \\
\hline TG $(\mathrm{mmol} / \mathrm{l})^{\mathrm{a}}$ & $1.99 \pm 1.4$ & $1.6 \pm 0.75$ & $1.8 \pm 0.7$ & $1.35 \pm 0.6$ & $1.6 \pm 0.9$ & $1.1 \pm 0.5$ \\
\hline TC $(\mathrm{mmol} / \mathrm{l})$ & $4.9 \pm 1.0$ & $5.6 \pm 1.0$ & $4.7 \pm 1.2$ & $5.2 \pm 0.9$ & $5.3 \pm 1.3$ & $4.6 \pm 0.8$ \\
\hline HDL-C $(\mathrm{mmol} / \mathrm{l})$ & $1.4 \pm 0.5$ & $1.4 \pm 0.5$ & $1.4 \pm 0.3$ & $1.5 \pm 0.6$ & $1.3 \pm 0.4$ & $1.4 \pm 0.3$ \\
\hline LDL-C (mmol/l) & $2.6 \pm 0.7$ & $3.4 \pm 1$ & $2.5 \pm 0.96$ & $3.0 \pm 0.5$ & $3.2 \pm 1.0$ & $2.7 \pm 0.7$ \\
\hline Glucose $(\mathrm{mmol} / \mathrm{l})$ & $6.5 \pm 3.1$ & $5.7 \pm 0.9$ & $5.8 \pm 0.8$ & $5.4 \pm 0.9$ & $5.7 \pm 0.9$ & $5.5 \pm 0.5$ \\
\hline Sodium $(\mathrm{mmol} / \mathrm{l})$ & $142.3 \pm 3.7$ & $143.0 \pm 2.34$ & $142.0 \pm 1.2$ & $143.2 \pm 1.6$ & $142.6 \pm 1.76$ & $142.1 \pm 2.1$ \\
\hline Body mass $(\mathrm{kg})$ & $104.8 \pm 26.7$ & $104.8 \pm 17.28$ & $100.9 \pm 19.9$ & $99.3 \pm 30.4$ & $104.8 \pm 14.27$ & $98.7 \pm 18.1$ \\
\hline BMI $\left(\mathrm{kg} / \mathrm{m}^{2}\right)$ & $35.5 \pm 6.2$ & $36.9 \pm 6.31$ & $37.3 \pm 6.3$ & $33.7 \pm 6.6$ & $37.2 \pm 4.93$ & $34.3 \pm 4.2$ \\
\hline $\begin{array}{l}\text { Waist circumference } \\
(\mathrm{cm})\end{array}$ & $111.6 \pm 16.1$ & $111.5 \pm 15.04$ & $115.4 \pm 18.6$ & $108.6 \pm 20.5$ & $112.0 \pm 14.78$ & $107.8 \pm 13.0$ \\
\hline SBP $(\mathrm{mmHg})^{\mathrm{b}}$ & $148.6 \pm 17.6$ & $145.5 \pm 11.38$ & $132.2 \pm 14.6$ & $123.0 \pm 11.2$ & $137.9 \pm 11.12$ & $128.5 \pm 10.5$ \\
\hline DBP (mmHg) & $98.9 \pm 13.4$ & $92.3 \pm 6.98$ & $81.4 \pm 5.5$ & $75.2 \pm 10.1$ & $87.2 \pm 8.19$ & $86.5 \pm 6.5$ \\
\hline
\end{tabular}

BMI - body mass index; DBP-diastolic blood pressure; HDL - High Density Lipoprotein; LDL - Low Density Lipoprotein; SBP- systolic blood pressure; TC- total cholesterol; TG- triglycerides; WHR - waist to hip ratio;

aII Hypertensive vs II Normotensive $(\mathrm{p}<0.05)$

${ }^{b}$ DD Hypertensive vs DD Normotensive $(\mathrm{p}<0.05)$

${ }^{\mathrm{c} D D}$ Hypertensive vs DD Normotensive $(\mathrm{p}<0.05)$

\section{DISCUSSION}

The results of previous studies on the association of I/D polymorphism of the ACE gene with blood pressure found in the literature have been inconsistent. No association has been found between the I/D polymorphism and the blood pressure among DASH study subjects, or in other studies [3, 25]. Among
Polish studies, there is one by Bellwon et al., where no significant differences in the distribution of genotypes were found between normotensive (DD - 34\%, ID $40 \%$, II $-26 \%$ ) and hypertensive (DD - 39\%, ID $36 \%$, II $-25 \%$ ) groups [3]. Conversely, Niklas et al., who analyzed distribution of genotypes in patients with hypertension, reported that $28 \%$ of subjects had the DD genotype, $45 \%$ - ID genotype, and $27 \%$ - the 
II genotype [14]. Whereas Tsai et al. indicated the role of the I allele, which occurred more frequently in subjects with hypertension than in the control group [27]. Stolarczyk concluded that patients with hypertension more often have the DD genotype [23].

A meta-analysis conducted by Staessen et al. included 23 studies; it evaluated the effect of ACE gene polymorphism on the incidence of hypertension and demonstrated no associations with the presence of the D allele [22]. O'Donnel et al. demonstrated a sexrelated association between the value of blood pressure and the I/D polymorphism [15]. The odds ratio for the development of hypertension in male carriers of the DD genotype was significantly higher than in male carriers of the II genotype. Such associations were not found in females.

In the present study, arterial hypertension occurred in $49.3 \%$ of subjects, including $15.1 \% 15.1 \%$ with DD genotype, $21.9 \%$ with ID genotype and $12.3 \%$ with genotype II. Among hypertensive subjects, the least frequently occurring genotype was genotype II, whereas among normotensive subjects - the homozygotic DD genotype. Clear and statistically significant differences were observed in blood pressure values.

Namely, statistically significant differences were noted in the values of systolic and diastolic blood pressure between people with DD genotype with hypertension $(148 / 99 \mathrm{mmHg}$ ) and people with normotension $(123 / 75 \mathrm{mmHg})$. Carriers of DD and ID genotypes from the hypertensive group had higher systolic blood pressure values than those without hypertension.

According to most authors, the ID polymorphism of the ACE gene does not increase the tendency to develop hypertension either in Caucasians or Asians. Studies by Sierra et al. suggest that the D allele predisposes rather to complications of hypertension [21]. Our study indicates that the D allele may be associated with the incidence of hypertension. The ID genotype was associated with higher body weight $(104.8 \pm 15.7 \mathrm{~kg})$, a higher BMI $\left(37 \pm 5.6 \mathrm{~kg} / \mathrm{m}^{2}\right)$, a higher proportion of subjects who consumed alcohol, a lower proportion of subjects who were physically active, as well as higher total cholesterol and LDL-cholesterol levels. The DD genotype was associated with a higher proportion of smokers. These are well-known risk factors of hypertension. Moreover, there have been studies that did not demonstrate these associations $[3,7]$ or demonstrated associations only between single risk factors e.g. body weight and/or insulin sensitivity $[10,20]$. A meta-analysis (46 studies) conducted by Agerholm-Larsen evaluated the effect of ACE gene polymorphism on the risk of developing coronary artery disease or myocardial infarction and demonstrated an association between the incidence of coronary artery disease and I/D polymorphism in studies in small populations. However this association was not demonstrated in large-population studies [1]. A meta-analysis conducted by Staessen et al. showed a greater risk of coronary artery disease and infarction in the carriers of allele D [22]. A lack of consistent results suggests a need for further studies in larger groups, as well as studies on the associations between $\mathrm{ACE}$ gene polymorphism and the classic risk factors of atherosclerosis.

\section{Relationship between dietary factors and polymorphism of the ACE}

Our study showed significant differences in copper, vitamin $\mathrm{D}$, and dietary fiber consumption between the different genotypes. These diet ingredients may be associated with hypertension, which has been shown in a number of studies. Copper is necessary in the formation of the enzyme ceruloplazmin, and ensures the oxidation of serotonin, ascorbic acid, and catecholamines. Moreover, it constitutes part of enzymes necessary for processing hormone-like compounds, prostaglandins, which play a role in blood pressure regulation. That is why copper may indirectly affect blood pressure regulation, as it takes part in a number of metabolic processes [24]. Some clinical and experimental study results confirm disturbances in copper metabolism which accompany hypertension. In subjects with hypertension, Vivoli et al. [29] detected inverse correlations between systolic blood pressure and (copper-dependent) superoxide dismutase levels as well as between diastolic blood pressure and (copperdependent) lysyl oxidase levels.

The role of vitamin D3 and its association with hypertension is not fully explained. The involvement of vitamin D3 in blood pressure regulation is supported by the fact that receptors for vitamin D3 are located in organs involved in blood pressure regulation, i.e. in the central nervous system, kidney, adrenal glands, vascular wall, or the heart. Calcium-phosphorus homeostasis, which is mediated by vitamin $\mathrm{D}$, has been indicated as one of the numerous pathogenetic factors of hypertension. Helping to maintain the body's calciumphosphorus homeostasis, vitamin D3 can directly affect blood pressure regulation. This vitamin's role in the pathogenesis of arterial hypertension may be also due to its so-called "non-classic" effect via vitamin D's involvement in the immune system, the RAA system, endocrine gland regulation, endothelial function, etc. In a study by Pfeifer et al., 8-week supplementation of calcium alone in elderly women with vitamin $25(\mathrm{OH})$ D3 levels below $50 \mathrm{nmol} / \mathrm{L}$ was associated with lower systolic blood pressure values than those following supplementation of vitamin D3 and calcium combined [18]. On the other hand, three large prospective population studies conducted in 1976-1999 and known 
as Nurses' Health Study I (NHS I), Nurses' Health Study II (NHS II), and Health Professionals' Follow-up Study (HPFS) showed no protective effect of increased vitamin D3 consumption against the development of hypertension [6].

The DASH study demonstrated a role of dietary fiber in blood pressure reduction [4]. The study compared the effects of three different diets on blood pressure in normotensive and hypertensive subjects (who were receiving no drug treatment). Three diet types were analyzed: a typical American diet (control), an increased intake of fruit and vegetables, and the DASH diet consisting of an increased consumption of fruit, vegetables, and low-fat dairy products. The most beneficial results were obtained in the study group using the DASH diet. The resulting hypotensive effect of this diet - systolic blood pressure decreased by $5.5 \mathrm{mmHg}$ and diastolic by $3 \mathrm{mmHg}$ - was likely to have several contributing aspects, including large intake of dietary fiber of $32 \mathrm{~g} /$ day, vs. $11 \mathrm{~g} /$ day in the control group.

Our studies indicate that higher copper and fiber consumption and lower vitamin D consumption was associated with the $\mathrm{D}$ allele, which may suggest a possible association between dietary components and gene polymorphism and hypertension. A recent study by Japanese authors showed no differences in the consumption of energy and components of diet among different ACE genotypes [7]. However, reduction of body fat content in women with the DD genotype was demonstrated to be significantly lower than that in women with the II and ID genotypes.

Numerous epidemiological and clinical studies suggest that high consumption of salt is associated with hypertension, and thus with a higher risk of cardiovascular disease [12]. Our studies demonstrated that salt intake of over 5 g/day based on the consumption of products was detected in $34.5 \%$ of subjects with the ID genotype and in $40.9 \%$ of subjects with the DD genotype - that is, in the groups with higher blood pressure than that in the group with the II genotype. Similar associations have been found by other investigators [9]. Therefore, the results of our study indicate an association between the $\mathrm{D}$ allele and environmental factors, nonetheless, further studies in larger groups of subjects are recommended.

\section{CONCLUSIONS}

1. Hypertensive subjects more frequently they have the DD and ID genotypes, whereas normotensive subjects - the II genotype. The DD genotype is associated with higher blood pressure values.

2. Subjects with $D$ allele were characterized by lower vitamin D and higher Copper consumption than I allele carriers.
3. In group $\mathrm{D}$ allele had a higher percentage of people who smoke and drink alcohol.

4. Studies have shown a relationship between environmental and genetic factors and hypertension but more research is needed.

\section{Conflict of interest}

The authors declare no conflict of interest.

\section{REFERENCES}

1. Agerholm-Larsen B., Nordestgaard B.G., Steffensen R., Sørensen T.I., Jensen G., Tybjaerg-Hansen A.: ACE genepolymorphism: ischemic heart disease and longevity in 10,150 individuals. A case-referent and retrospective cohort study based on the Copenhagen City Heart Study. Circulation 1997;95:2358-2367.

2. Barlassina C., Lanzani C., Manunta P., Bianchi G.: Genetics of essentials hypertension: from familie to genes. J Am Soc Nephrol 2002;13:155-164.

3. Bellwon J., Gruchała M., Siebert J., Wasag B., Ochman K., Targoński R.W., Dubaniewicz W., Chlebus K., Gałaska R., Rynkiewicz A.: Współwystępowanie wariantów polimorficznych I/D genu ACE i A1166C genu receptora AT1 angiotensyny II a ciśnienie tętnicze u mężczyzn bez jawnych klinicznie schorzeń miażdżycopochodnych. [Association of the I/D polymorphism of ACE and A1166C polymorphism of the angiotensin II AT1 receptor gene and bloodpreassure in men without clinical manifestations of atherosclerotic diseases]. Nadciśnienie Tętnicze 2000;4,4:261-268.

4. Bray G.A., Vollmer W.M., Sacks F.M., Obarzanek E., Svetkey L.P., Appel L.J.; DASH Collaborative Research Group: A further subgroup analysis of the effects of the DASH diet and three dietary sodium levels on blood pressure: results of the DASH-Sodium Trial. Am J Cardiol 2004;94:222-227.

5. Diet, nutrition and the prevention of chronic diseases. Report of a Joint WHO/FAO Expert Consultation. WHO Geneva. WHO Technical Report Series 2003;916:1-149. https://apps.who.int/iris/bitstream/handle/10665/42665/ WHO_TRS_916.pdf;jsessionid=B5E0BF9CCEB76AD 7B0A32464DF3C749C?sequence $=1$

6. Forman J.P., Bischoff-Ferrari H.A., Willett W.C., Stampfer M.J., Curhan G.C.: Vitamin D intake and risk of incident hypertension. Results from three large prospective cohort studies. Hypertension 2005;46:676682.

7. Hamada T., Kotani K., Nagai N., Tsuzaki K., Sano Y., Matsuoka Y., Fujibayashi M., Kiyohara N., Tanaka S., Yoshimura M., Egawa K., Kitagawa Y., Kiso Y., Moritani T., Sakane N.: Genetic polymorphisms of the renin-angiotensin system and obesity-related metabolic changes in response to low-energy diets in obese women. Nutrition 2011;27(1):34-39.

8. Jarosz M.: Normy żywienia dla populacji Polski. Warszawa, Wyd. IŻŻ, 2017.

9. Kleij F.G., Jong P.E., Henning R.H., Zeeuw D., Navis G.: Enhanced responses of blood pressure, renal function, 
and aldosterone to angiotensin I in the DD genotype are blunted by low sodium intake. J Am Soc Nephrol 2002;13(4):1025-1033.

10. Kourlaba G., Pitsiladis Y.P., Lagou V., Grammatikaki E., Moran C.N., Kondaki K., Roma-Giannikou E., Manios $Y$ :: Interaction effects between total energy and macronutrient intakes and angiotensin-converting enzyme 1 (ACE) I/D polymorphism on adiposityrelated phenotypes in toddlers and preschoolers: the Growth, Exercise and Nutrition Epidemiological Study in pre Schoolers: the GENESIS study. Br J Nutr 2008;100:1333-1340.

11. Kunachowicz H., Przygoda B., Nadolna I., Iwanow K.: Tabele składu i wartości odżywczej żywności. Warszawa, Wyd. Lek. PZWL, 2005.

12.LawrenceJ., Appel L.J., Frohlich E.D., HallJ.E., Pearson T.A., Sacco R.L., Seals D.R., Sacks F.M., Sidney C., Smith S.C., Vafiadis D.K., Van Horn L.V.: AHA Presidential Advisory TheImportance of Population-Wide Sodium Reduction as a Means to Prevent Cardiovascular Disease and Stroke A Call to Action From the American Heart Association. Circulation 2011;123:1138-1143 doi: 10.1161/CIR.0b013e31820d0793.

13.Lindpaintner K., Pfeffer M.A.: A prospective evaluation of an angiotensin-converting-enzyme gene polymorphism and the risk of ischemic heart disease. $\mathrm{N}$ Engel J Med 1995;332(11):706-711.

14. Niklas K., Niklas A., Gtuszek J.: Czy wpływ leczenia inhibitorem konwertazy angiotensyny na insulinooporność wiąże się $\mathrm{z}$ polimorfizmem insercyjno-delecyjnym genu ACE? Arterial Hypertension 2011;5(15):299-311.

15. O'Donnell C.J., Lindpaintner K., Larson M.G., Rao V.S., Ordovas J.M., Schaefer E.J., Myers R.H., Levy $D$.: Evidence for association and genetic linkage of the angiotensin-converting enzyme locus with hypertension and blood pressure in men but not in women in Framingham Heart Study. Circulation 1998;97(18):1766-1772.

16. Opie L.H.: Inhibitory konwertazy angiotensyny. Via Medica. Gdańsk. 2000.

17. Pachocka L.M., Włodarczyk M., Nowicka G., Kłosiewicz-Latoszek L., Wolańska D., Stolarska I.: Polimorfizm TaqIB genu CETP a stężenie lipidów u pacjentów z nadwagą i otyłością. Rocz Panstw Zakl Hig 2012;63(2):149-154.

18. Pfeifer M., Begerow B., Minne H.W., Nachtigall D., Hansen $C$.: Effects of a short-term vitamin D3 and calcium supplementation on blood pressure and parathyroid hormone levels in elderly women. J Clin Endocrinol Metab 2001;86:1633-1637.

19. Rigat B., Hubert C., Alhenc-Gel F., Cambien F.: An insertion-deletion polymorphism in the angiotensin I-converting enzyme gene accounting for half the variance of serum enzyme levels. J Clin Invest 1990;86(4):1343-1346 doi: 10.1172/JCI114844.

20.Ryan A.S., Nicklas B.J., Berman D.M., Ferrell R.E.: The insertion/deletion polymorphism of the ACE gene is related to insulin sensitivity in overweight women. Diabetes Care 2001; 24(9):1646-52

21. Sierra C., Coca A., Gómez-Angelats E., Poch E., Sobrino $J$. , de la Sierra A.: Renin-angiotensin system genetic polymorphism and cerebral white matter lesions in essential hypertension. Hypertension 2002;39:343-347.

22.Staessen J.A., Wang J.G., Ginocchio G., Petrov V., Saavedra A.P., Soubrier F., Vlietinck R., Fagard R.: The deletion /insertion polymorphism of the angiotensin converting enzyme and cardiovascular -renal risk. J Hypertens 1997;15:1579-1592.

23. Stolarczyk D., Chmara E., Mrozikiewicz P.M., Brokl B., Mrozikiewicz A.: Polimorfizm genu ACE w wybranej populacji Wielkopolski. Post Farmakoter 2000;1(4):2627.

24.Suliburska J., Duda G.: Żywieniowe czynniki ryzyka rozwoju pierwotnego nadciśnienia tętniczego. Bromat Chem Toksykol 2006;3:205-210.

25.Svetkey L.P., Moore T.J., Simons-Morton D.G., Appel L.J., Bray G.A., Sacks F.M., Ard J.D., Mortensen R.M., Mitchell S.R., Conlin P.R., Kesari M.: DASH collaborative research group. Angiotensinogen genotype and blood pressure response in the Dietary Approaches to Stop Hypertension (DASH) study. J Hypertens 2001;19(11):1949-56.

26. Third Report of the National Cholesterol Education Program (NCEP) Expert Panel on Detection, Evaluation, and Treatment of High Blood Cholesterol in Adults (Adult Treatment Panel III) final report. Circulation 2002:17;106(25):3143-3421.

27. Tsai C.T., Fallin, D.D., Chiang, F T., Hwang, J J., Lai, L.P., Hsu, K.L., Tseng, Y.Z.: Angiotensinogen gene haplotype and hypertension: Interaction with ACE gene I allele. Hypertension 2003;41(1), 9-15. doi. org/10.1161/01.HYP.0000045080.28739.12

28.Wang X., Prins B.P., Sõber S., Laan M., Snieder H.: Beyond genome-wide association studies: new strategies for identifying genetic determinants of hypertension. Curr Hypertens Rep 2011;13(6):442-51.

29. Vivoli G., Brgomi M., Rovesti S., Pinotti M., Caselgrandi E.: Zinc, copper and zinc or copper-dependent enzymes in human hypertension. Biol Trace Element Res 1995;49:97-106.

30.Zdrojewski T., Bandosz P., Szpakowski P.: Rozpowszechnienie głównych czynników ryzyka chorób układu sercowo-naczyniowego w Polsce. Wyniki badań NATPOL PLUS. Kardiol Pol 2004;61(4):1-26.

Received: 21.03 .2020

Accepted: 15.05.2020 